\title{
Ethical Competences for Democratic Citizenship at School, University and in Family
}

\author{
Maria Rosa Buxarrais, Elena Noguera and Francisco Esteban
}

We live in a pluralistic world, in a democratic society, where different ways of seeing and coping with life coexist. The evolution of society is complex and uncertain, and people must face great challenges, confusion and disorientation that do not help them to find their way forward in life.

Moreover, the multiculturalism of our societies, especially the most advanced ones, requires learning how to live together. It is not only living side by side during a specific stage of life, with individuals of different characters, intellectual levels, ethnicity or religion. We will have to set in childhood and youth the fundamentals of this coexistence so that these persist into adulthood.

What kind of education is appropriate to build a democratic society? We define a democracy as a form of social organization in which individuals can exercise their autonomous and participatory character, remembering in a meaningful way the aims of politics and of all the spheres of civil society that, mainly, are the service of the affected by the decisions that are made in them (Cortina, 1993). Therefore, a democratic society will be based on values such as autonomy, solidarity and dialogue between cultures.

Citizenship education in pluralistic and democratic societies implies a process of personal and autonomous construction that takes place thanks to the coexistence and the interrelation with the other people of the community. We propose an education that promotes the acceptance of others, active tolerance and respect, knowledge of the other, involvement in collective projects, factors that contribute to propose an intercultural education model (Hoyos \& Martínez, 2004).

Educating citizens who are critical and committed to the reality of their time has become one of the tasks most demanded by today's society. In spite of its importance it is not being attended as it would correspond, so it is urgent to help build the figure of the citizen in this time of change. One of the most pressing challenges facing education today is how to prepare citizens to respond to what will come in the near future. 
In Spain, citizenship education consists of an area that is promoted in schools with the aim to fostering the harmonious co-existence and mutual beneficial development of individuals and of the communities they are part of (Buxarrais, 1997). In democratic societies citizenship education supports students in becoming active, informed and responsible citizens, who are willing and able to take responsibility for themselves and their communities at the local, regional, national and international level.

We want to mention some empirical inputs collected as part of a comparative, international study involving 28 State Members of the European Union (Veugelers, De Groot, \& Stolk, 2017). The aim of this effort was to analyse the policies related with the teaching of core civic values (democracy, participation, tolerance) in secondary education, and how were those policies spelled out in practice, in terms of curricula, methods and school culture. We were also interested in the role of the different actors involved in the teaching of those values: teachers, students, local communities, NGOS and other civil society organizations.

For that purpose, we adopted an exploratory, qualitative approach (Stake 2010) and employed an intentional sample that included an Official from the Education Ministry, two experts working with NGOS, and four teachers from the secondary (or high school) level. All of them were pleased to participate and expose their views answering an ad hoc questionnaire. As first step, it was employed a written questionnaire about the following subthemes: educational policies, educational contents, school culture, participation, history and future of the educational policies. Each country had a key-informant (an university professor) selected because his/her expertise in this field. The first author of this chapter was the Spanish representative or key informant.

As second step we prepared another questionnaire for consulting other types of key-informants: high schools' teachers, officials in charge of educational policies and NGOs representatives. Since 2012, the Spanish public curriculum does not demand teaching about citizenship values. Thus, one might assume that both teachers and educational institutions would have renounced to bother themselves with this apparently superfluous task. Nothing, however, could be further from the truth. As our interviewees explained, citizenship education survives among us because a number of teachers and schools insist on promoting an active, critical and responsible citizenship, as well as democratic values, through very diverse educational practices.

In short, most schools considered by us reported, in one way or another, to work on the following themes: (1) identity and dignity of persons; (2) understanding and respect toward interpersonal relationships; and (3) coexistence and social values. But beyond those common themes there are few shared 
theoretical frameworks or practical guidelines. The Ministry of Education consults, occasionally, to some NGOs about designs and practices of Values Education. However, only a few schools use the didactic materials prepared by the NGOs, since ultimately these decisions belong to the schools Head Teachers.

Citizenship education needs to help students develop knowledge, skills, attitudes and values in four broad competence areas (Buxarrais, 1997): (1) interacting effectively and constructively with others; (2) thinking critically; (3) acting in a socially responsible manner; and (4) acting democratically.

We need an education that allows us to understand critically our world, to be interested in knowing more about those controversial issues socially and ethically, to recognize the value of diversity, to argue with quality, to be persevering in the defence of our rights, to accept the limitations of personal and community life, to value the common good and participate collaboratively and actively in its achievement. Citizenship education is not only teaching to estimate certain specific values of our culture, or those that base the Declaration Universal of Human Rights or the democratic constitutions of the countries, is also and above all, providing cognitive resources to people so that they can learn ethically throughout their lives and so that they have illusion and are able to participate in the collaborative construction of a citizenship active and democratic.

Citizenship education involves not only teaching and learning of relevant topics in the classroom, but also the practical experiences gained through activities in school and wider society that are designed to prepare students for their role as citizens. Teachers and school leaders play a key role in this learning process. The training and support provided to them is therefore central to the effective implementation of citizenship education.

\section{Theoretical Background}

A mature civic and democratic behavior does not only depend on the ideals and moral purposes of a person, but also and above all on their ability to apply those ideals to their daily life in a consistent and differentiated way. In that sense, our proposal of intervention in citizenship education has been called: Model of Construction of Moral Personality (Buxarrais, Martínez, Puig, \& Trilla, 1995). We understand that citizenship education is a variety of moral education, based on the conviction that morality is not something given in advance, assumed, or simply decided or chosen; instead, morality must be generated by a complex effort in the processing or reprocessing of lifestyles and values that are considered correct and appropriate for each situation. 
Therefore, citizenship education involves a constructive task: ethics is not discovered, but it is built. In this way, it should be understood as a task of building or rebuilding personal and collective valuable moral ways. Therefore, it is not a construction alone, nor is it devoid of past and outside any historical context. On the other hand: it is a socially influenced task, which also has precedents and cultural elements of value that undoubtedly help shape their results. The moral is ultimately a cultural product whose creation depends on each subject and whole.

But how and through what elements and dynamics can the teachers develop these ideas in the classroom? To answer these questions, we must start from the premise that a proposal for citizenship education cannot consist only of proposed values to teach, but consists mainly in proposing what conditions educational institutions, schools, colleges or universities must meet in order to be an optimal scenario in which childhood, adolescence and youth could develop all the human dimensions that allow them to evaluate, estimate, accept and build values.

Educating from the moral point of view is, above all, providing conditions, generating climates and helping recreate values, creating new ways of being, valuing their lives and guiding the ones who are learning to be able not only to find their place in the world but also be the author and master of their actions, to achieve an ethical learning.

The kind of ethical learning that we wish to defend draws upon a theoretical and practical model known as 'the construction of moral personality'. This model has been used for many years in our pre-university education and it brings together ideas from other models that focus on development and moral reasoning (Kohlberg 1981, 1984; Colby \& Kohlberg, 1987; Gibbs, 2003), emotion and sensation (Noddings, 2008; Prinz, 2009) and moral character (Hartshorne \& May, 1930; Berkowitz, 2002; Lapsley \& Clark, 2005; Carr, 2008; Doris, 2008; Nucci \& Narváez, 2008).

The moral personality model also takes on board the contributions of integrated models in moral developmental theory (Turiel, 1984; Rest, 1986). The goal of our ethical learning model is to provide students with a firm moral grounding, both as private individuals and as members of collectives (Tirri \& Nokelainen, 2011; Veugelers, 2011).

The model is based on the following premises: (1) knowledge, as the cognitive-behavioural tradition proposes, must favour the use of communicative rationality and dialogue in dispute resolution; (2) in accordance with Kantian ethics (Kant, 1785/2008), people must be treated as ends in themselves and their freedom and individuality must be respected; (3) in accordance with Aristotle (1998) we must, in the notion of our future as virtuous individuals, 
recognize a teleological dimension; and (4) again with reference to Aristotle, students should be called upon as individuals to act within and exert influence upon their community (Aristotle, 1962).

This ethical learning model stems from educational work carried out in eight areas of development that together constitute what we call ethical learning (Puig \& Martín, 1998): self-knowledge; autonomy and self-regulation; dialogue; the ability to transform the environment; empathy or social perspective; social skills; critical understanding of reality; and finally, reasoning. These eight areas are further assigned to three basic learning categories: the construction of self, learning in fellowship, and socio-moral reflection.

Construction of self-entails: self-knowledge, autonomy and self-control. This category involves individuals learning to be autonomous within their communities, acquiring an understanding of who they are through their relationships with others, being able to evaluate this understanding, and, finally, learning how morally- and ethically-challenging scenarios require them to weigh up or temper the way they behave. Construction of self thus involves the formation of our way of being and everything that encompasses our intrapersonal sphere at what has been called a 'microethical' level (Apel, 1985). Within this category, ethical and moral teaching must ensure that students reflect on the kinds of professionals and citizens they aspire to be. Finally, construction of self also teaches students to acquire a series of values: the importance of effort, perseverance, personal growth, the acceptance of one's own vulnerability and of setbacks, and freedom.

Learning in fellowship entails ability in dialogue and the acquisition of empathy or social perspective, as well as of social skills. Primarily, this category trains individuals in the skills they need to live with others. It involves learning and defending norms or standards that are recognized as socially beneficial, whether or not they are the result of formal legislation and requires individuals to acquire a set of abilities and social skills ranging from openness and transparency to sensitivity with regard to the principles of community value. Finally, it also means learning to assess knowledge in terms of its social value and understanding that knowledge gained for example at the university is not an end in itself but the means by which to return to the community what rightfully belongs to it. Insofar as it helps individuals to be aware of ethical and moral issues at local, national and international levels of community life, this category can be said to provide teaching at a 'mesoethical' level (Apel, 1985). It also touches on the fourth component in the Four-Component Model: moral character or courage (Rest, 1986). In addition, learning in fellowship challenges certain existing notions such as otherness, as well as topics in values education such as civility, hospitality, brotherhood and dialogue. It does this by reiterating the idea that twenty-first century European educational systems students 
should behave as an 'elite' in the etymological sense of this term, defined not as an exclusive group but as a set of individuals who are actually involved in the community because they are responsible for their actions and omissions (Steiner, 2004).

The third category, socio-moral reflection, entails a critical understanding of reality and an ability to engage in moral and ethical reasoning. This category trains people to consider real and hypothetical scenarios in which there is controversy or conflict and to be able to anticipate conflict as the potential outcome of a given situation. It helps students learn the importance of reflecting before acting or of acting according to a process of reasoning. Learning in socio-moral reflection is therefore a way of experiencing knowledge in its ethical and moral dimensions, of questioning that knowledge and of making objective, ethically-informed decisions. This category operates at what can be called a 'macroethical' level (Apel, 1985). Some of the values that underpin socio-moral reflection are justice, human dignity, respect, hope, interest, rigour and criticism.

\section{Aims of the Module and Curriculum Guidelines}

Our proposal for ethical competencies does not only consist of proposing a set of values to be fostered, but also to condition the social milieu on a series of requirements so that it becomes a fertile moral soil. We expect that students acquire knowledges and strategies in order they can promote and cultivate democracy as a way of living, understand participation in collective projects and practice the search for the common benefit agreements. These are goals that can only be achieved by creating an atmosphere based on caring relationships among all. This also implies the alignment of the educational institutions with the family in order to contribute to the general process of moral human development, and to the development of specific ethical abilities: to recognize, understand, select, build, assess and apply moral values. But as every area has their own identity we will treat them independently, unless we find common dimensions and aspects.

On completion of this module, the student should be able to be aware of the current level of ethical competences in school, university and family, and to analyse real life and hypothetical moral situations relevant for those contexts

\section{1} At School

\subsubsection{Aims}

- To analyse ethical competencies for a democratic citizenship that we should foster in schools and investigate the possible pros and cons of them. 
- To learn about different educational strategies for the development of ethical competences, and to examine which ones seem the best suited for their classrooms or schools.

\subsubsection{Curriculum Guidelines}

At least four education scenarios in values and moral development can be highlighted in school: (1) peer interaction, (2) teacher action, (3) the moral climate of the institution and (4) the double transversality of its contents. Peer interactions and the direct action of teachers are the two most natural settings in which we form our personality. Teachers, through the exercise of their duties, should provide conditions to appreciate values, knowledge management, mediate conflicts and positively catalyse human expression through verbal and nonverbal forms that allow our artistic, physical, emotional and affective manifestations.

However, the school as a whole and the double transversality of the contents of specific values education programs are also particularly relevant scenarios for the construction of the moral personality of students: the moral climate of the school is a development factor and can be of moral progress and the double transversality of the contents shows us again how contents are not only informative but also procedures and attitudes that shape our behaviours and feelings. The school must be effectively impregnated with those contents or values that are intended to be appreciated by its students. To promote and cultivate democracy as a way of living, to understand participation in collective projects, and to practice the search for common good agreements are goals that can only be achieved by creating an atmosphere that represents these values, and particularly caring relationships between teachers, the students and ultimately, of all who take part in the school life.

We bet on a curriculum in relation to reality and context, and for active educational and social interventions in our community in favour of community development. We consider that service-learning could be a good example, a pedagogical proposal that combines learning processes and community service in a single well-articulated project in which participants are trained by working on the real needs of the environment with the aim of improving it (Puig, Batlle, Bosch, \& Palos, 2006). It is a typology of projects that links all kinds of learning to carry out actions that respond to social demands. It is characterized by being socially useful, flexible and adapted to the recipients; for performing a service where you learn by collaborating within the framework of reciprocity; by entering into a process of acquiring knowledge and skills for life; for requiring active and reflective participation; for needing parliamentary networks and instances of collaboration and support; and for having a 
formative and transformative impact (Puig, 2012). Thus, Service Learning requires contact with other entities that could provide spaces for action - a type of institutional collaboration we call "educational experience's partnerships" (Graell, 2015).

A basic definition of the partnership proposed by Glendinning (2002) stipulates that the partnership constitutes a joint work agreement between organizations, institutions or independent groups that decide to collaborate in pursuit of common objectives; they need to create organizational processes to achieve this goal; implement their action program together; and share risks, responsibilities and benefits. The partnership that we would call educative arises from social and educational responsibility towards citizenship: an education that is socially committed to the reality in which it is located. Social transformation arises from social actions spurred by educational projects.

We have the option of visiting the following non-governmental organizations:

- Fundació Solidaritat UB http://www.solidaritat.ub.edu/

- Institut Diversitas http://www.institutdiversitas.org/

- Oxfam Intermón https://www.oxfamintermon.org/es

- Fundació MigraStudium http://www.migrastudium.org/

\subsubsection{Examples of Activities}

\section{ACTIVITY 1: Recognizing the group}

The facilitator informs the group that he or she will suggest some labels or categories to visualize common and divergent aspects of the group. This, in order to promote the awareness of belonging to a group with different individual profiles or personalities, but nevertheless with possible common interests or projects to be developed taking advantage of the different capacities of its members.

Examples of labels or categories:

- Year/month of birth

- Place of birth (neighbourhood, city, country, etc.)

- Languages spoken

- School/course

- Extracurricular activities

- Instruments played

- Pet animals

- Profession to be exercised

- Types of positions carried out in different contexts and institutions

- Types of participation in projects

- Topics that concern them about their city (or their school) 
After each label or slogan, the participants are grouped and then a small debate is opened aloud to analyse what has happened and express some anecdotes or remarks. Once the instructions have been made, the participants are asked to think of labels that interest them. Once this phase of the activity is finished, the participants are asked to group again according to a label or category that facilitates the division of the large group into small groups of more or less five participants.

Then they are asked to make some balance, to think about what "group photography" has emerged from the activity and write a definition that specifies their feelings about belonging to the group. The different groups share their results and a debate is opened. Then the "secretaries" of each group come together to write a single definition as an element of collective memory, and to summarize in three points what everyone would have to contribute to the collective so that it could be considered a true group.

ACTIVITY 2: Intercultural dialogue and democracy

- Answer the following unfinished questions and unfinished phrases about the intercultural dialogue and democracy.

First it is answered individually or in pairs and then they will be read, comparing and commenting on the answers to each unfinished question or phrase.

1. The intercultural dialogue is ...

2. Democracy is ...

3. Intercultural dialogue is positive if ...

4. What difficulties do we find when we talk with other people? ...

5. When we talk, should we always be sincere? Why? ...

6. What would you demand from a person who would like to talk to you? ...

7. What would you demand of yourself? ...

8. The objective of the intercultural dialogue is ...

9. Think about situations in which the intercultural dialogue favoured the solution of a situation and in others in which its lack harmed it ...

10. Say what you think about this statement: "Dialogue is impossible, the strongest party always wins" ...

11. Can there be a correct realization of a participation project if the conditions of a good dialogue are not followed?

A few options for incorporating to the filling of uncomplete sentences activity for elementary schools:

- Have you ever wished to live in a different country? Why or why not?

- Do you know people from other countries or cultures?

- Do you have friends or relatives from other countries or cultures? 
- What would you say are the main differences between them and us?

- A bad thing of the school having people from different countries or cultures is ...

- A good thing of the school having people from different countries or cultures is ...

- Some time ago only Italians used to eat pasta and pizza, only Japanese used to eat sushi, and most people around the world had never eaten a hamburger. Now all this has changed a lot. Are these kind of changes are good or bad? Why?

\section{ACTIVITY 3}

An option, for high school or university students could be:

Read the following explanation about the differences between the meaning of the words "multicultural" and "intercultural".

Multicultural education uses learning about other cultures in order to produce acceptance, or at least tolerance, of these cultures. Intercultural Education aims to go beyond passive coexistence, to achieve a developing and sustainable way of living together in multicultural societies through the creation of understanding of, respect for and dialogue between the different cultural groups. (UNESCO, 2006, p. 18)

Given this explanation, do you think the education you have received until now is mostly monocultural, multicultural, intercultural? Why? Can you offer an example?

ACTIVITY 4: Educational telecommunication networks

The Educational telecommunication networks aims at the improvement and the promotion of ІСТ-based innovation of education.

It attempts to achieve its aims by:

- Promoting collaboration and cooperation between pupils, students, educators and researchers.

- Availing access to international networks.

- Promoting and supporting professional development of teachers and educators.

- Developing innovative concepts, instruments and content.

- Performing research.

Here you have some links to the Educational telecommunication networks:

- International Education and Resource Network, iEARN. http://www.iearn.org 
- ESP European School Project http://www.espnet.eu/

- GS Global Schoolhouse de la GSN, Global Schoolnet Foundation http://www.gsn.org

- Kidlink http://www.kidlink.org

Think individually and share with others about the areas and moral dimensions that these networks and projects can help to develop.

\subsubsection{Assessment}

1. Active participation in face-to-face classes. Attendance at seminars with professors and students in order to present and share ideas and discuss readings ( $20 \%$ of the final grade).

2. To analyse suggested readings and writing essays about them $(40 \%$ of the final grade).

3. Analysis of case studies in group (30\% of the final mark).

4. NGOS and schools' visits (10\%).

The evaluation of this proposal has a formative meaning, to improve attitudes and acquisition of intercultural and democratic values (tolerance, recognition and acceptance of other cultures, citizenship and democratic conscience, solidarity, etc.) It is important to have an auto-evaluation exercise, so students can think about their own opinions and attitudes. It is interesting to share them with other students and the professor, so the group will know more about the class.

Preparation of one-page essay on the ideas worked on this part of the module.

\subsection{At University}

\subsubsection{Aims}

- To know the history and tradition of university education, its genesis and evolution from the 12th century to the present day.

- To know the philosophical and pedagogical principles that give meaning to the idea of university education, as well as the different ways in which they are interpreted.

- To interpret the different positions around the idea of university education, its epistemological foundations, as well as the pros and cons of each of them.

- To analyse the idea of university education in a prospective and speculative way, that is, considering contemporary circumstances. 


\subsubsection{Examples of Activities}

Activities that will be worked with students both face-to-face and virtual:

ACTIVITY 1. In the famous metaphor of Bernardo de Chartres (circa 1130), the intellectuals are represented as those men who were standing on the shoulders of the ancients, in order to see beyond them. What do you think that representation means for the first universities?

ACTIVITY 2. Hardly had the first universities consolidated, when already could be heard complaints like those of the eminent chancellor of the University of Paris (1218 and 1236) Philippus de Grevia: "In another time, when each master taught independently and when the name of the university was unknown, there were more lessons and discussions and more interest in the things of knowledge. However, now when you have met in a university, the lessons and discussions have become less frequent; everything is done hastily, little is learned, and the time necessary for the student is wasted in meetings and disputes. While the old men debate in their meetings and establish statutes, the young people organize base plots and plan their night attacks". Think about this quote based on what was explained and worked on in this part of the module.

ACTIVITY 3. Erasmus writes in Familiarum colloquiorum formulae (1512-22): "not only to teach students a refined language but also and above all to educate them for life". Relate the said statement with the ideas considered in this module.

ACTIVITY 4. Reflect on the following quote from Humboldt: "The human can only develop in the form of cooperation ... so that the fruits achieved by some satisfy others, and all can see the general, original force that in the individual only reflects in a concrete way or derivative ...."

ACTIVITY 5. Comment on the following quote from Humboldt: "The State must keep in mind that, in reality, its intervention does not stimulate nor can it stimulate the achievement of the university's own aims, which, far from it, its interference is always disturbing; that without him things would in themselves go infinitely better", and continues: "The State must have the intimate conviction that, inasmuch as universities comply with the ultimate goal that corresponds to them, they also fulfil their own purposes, and also, from a higher point of view, from a point of view that allows a much greater concentration and an agglutination of forces that the State cannot put in motion".

ACTIVITY 6. Comment on the following quote from Richard Sennet (Corrosion of Character) in relation to university education: "How can a human being develop the story of his identity and personal history in a university made of episodes and fragments?" 


\subsubsection{Assessment}

1. A review of between 4 and 5 pages of each of the following texts:

- Laredo, P. (2007). Revisiting the third mission of universities: Toward a renewed categorization of university activities. Higher Education Policy, 20(4), 441-456.

- MacIntyre, A. (2009). The very idea of a university: Aristotle, Newman and Us. British Journal of Education, 57(4), 347-362.

2. Participation in a virtual forum on some aspect of university education that will be proposed by the professors of the module.

3. Preparation of a final 3-page essay on the ideas worked on in this part of the module.

\subsection{At Families}

3.3.1 Aims

1. To promote and collaborate in organized actions for enhancing the contribution of families to citizenship development.

2. To analyse in a critical way the most important factors currently impinging upon family education: mass media, gender and intergenerational relationships, multiculturality, sustainable development, mass consumption, etc.

3. To design and to implement a support program for families about how to foster moral values in children and youngsters.

\subsubsection{Contents}

1. Family and families

1.1. Origins and concepts.

1.2. Familiar diversity.

1.3. Families in the Information and Technology Society.

2. Why and how to educate in values in the family context.

2.1. Family paper in values development.

2.2. Familiar culture: dimensions.

2.3. How values are learned and constructed in the family.

2.4. Relation between family and school.

3. Controversial situations in the family context.

3.1. Using technologies and social media.

3.2. Responsible consumption: the value of austerity.

3.3. Conciliation of familiar, personal and working life: the value of responsibility.

3.4. Leisure management.

4. Pedagogical proposals in the family context related to values education. 


\subsubsection{Examples of Activities}

ACTIVITY 1: Analyse the underlying family model in a movie. The teacher provides a list of 20 films where various family models appear.

ACTIVITY 2: Carry out an interview with parents of different types (nuclear, single-parent, reconstituted, etc.), to know what kind of family practices they carry out in order to educate in values.

ACTIVITY 3: Read one of the following articles and propose a set of recommendations for families to educate in values.

Dunn, J. (2006). Moral development in early childhood and social interaction in the family. In M. Killen \& J. G. Smetana (Eds.), Handbook of Moral Development (pp. 331-350). Mahwah, NJ: Lawrence Erlbaum Associates.

Halstead, J. Mark (1999). Moral Education in Family Life: The effects of diversity.Journal of Moral Education, 28(3), 265-281.

\subsubsection{Assessment}

1. Final project that will be worked on throughout the course. The project consists of, firstly, to answer some global questions and, secondly, to list a glossary of concepts related to the learning outcomes of the Master. The project will gather 16 contributions taking in account the questionanswer part and the glossary ( $60 \%$ of the final mark).

2. Attendance and the participation in class: Student may choose to expose any content related to the subject in class, proposing some debate, or to organize a talk with families. Teachers will choose the speech topic $(40 \%)$.

\section{$4 \quad$ Process and Conclusions}

The actual module will run spring 2019. So at this time no evaluation can be presented.

We present here the evaluation of one of the students who attend the Intensive Programme. Having the opportunity to know different countries and learn from their education system was an extraordinary experience. As a Chilean student at the University of Barcelona, who was studying the Master's Degree in Education in Values and Citizens, to be able to participate in the Erasmus experience was like a dream come true. In the first place, sharing the day to day with students of different nationalities was really enriching, because I could learn from each one of them his way of contributing to society, from his own studies and realities of life. In addition, the teachers who participated in 
each presentation, exposed topics related to what I was studying, which was much more significant. The topics addressed were mainly related to citizenship, interculturality, inclusion, civic participation, and democracy, respect for human rights, the ethics of care, education in values, ethical sensitivity, moral and ethical virtues that educators should have, as well as the importance of fighting against violence and the different ways in which it manifests itself. In addition, each student had the opportunity to present the culture and educational system of their country of origin, and that exercise was quite positive for knowing more about each other.

The first seven days we were in Tallinn, they were quite intense from 9 a.m. until 6 p.m. in classes, where every day we had a different activity, either linked to the themes or to the recreational activities, which generated a space of confidence and relaxation for all. Every day we could be in a new place in the city, which opened the doors to us to know a completely different culture.

The three days we spent in Helsinki were very intense, although academically we didn't learn as much as in Estonia. In any case, it was a very rewarding experience. In both cities we had the opportunity to go to a public school, where they treated us very kindly and we knew superficially their educational system. Visiting both schools freely and understanding the way in which they develop topics such as freedom, human rights, autonomy, interculturality, democracy, values education, respect and everything that it involves, was a space of knowledge and openness towards different ways of educating.

To summarise I consider that this experience changed a part of me, as a person and as an educator, since it expands your mind and your way of seeing the world, learning, exchanging, knowing realities, ideas and key topics to transform society, such as:

- The way to eradicate the stereotypes and prejudices that exist towards cultures or people in general and how harmful they are.

- How citizenship and democracy are worked at the educational level.

- How schools can be truly inclusive and intercultural spaces.

- The ethical competences in the school, the conditions and strategies to address them.

- The construction of the moral personality applied to the classroom.

- The importance of the ethics of care and how to apply it in schools.

- Work participation at all times, highlighting that students are already citizens with the right to freely express their opinions.

- Among many other subjects, but what really stands out is the cultural exchange that I had the chance to live, in a friendly and welcoming academic environment. 
There are several topics that could be sequenced and scheduled not interesting for the students of the Master, but necessary for a better understanding of citizenship and multiculturalism. In short, the assessment of the visit and activities is very positive. Moreover, it is even recommended to extend this activity to other contexts and realities due to its high training value.

\section{References}

Apel, K. (1985). La transformación de la filosofía [The transformation of philosophy]. Madrid: Taurus.

Aristotle. (1962). The Politics. London: Penguin Books.

Aristotle. (1998). The Nicomachean ethics. New York, NY: Oxford University Press.

Bauman, Z. (2005). Postmodern ethics. London: Blackwell.

Berkowitz, M. (2002). The science of character education. In W. Damon (Ed.), Bringing in a new era in character education (pp. 43-63). Standford, CA: Standford University Press.

Biesta, G., \& Lawy, R. (2006). From teaching citizenship to learning democracy: Overcoming individualism in research, policy and practice. Cambridge Journal of Education, $36(1), 63-79$.

Burroughs, M. R. (2017). Educating the whole child: social-emotional learning and ethics education, Ethics and Education, 12(2), 218-232.

Buxarrais, M. R. (1997). La formación del profesorado en educación en valores. Propuestas y materiales [Teachers' formation in values education. Proposals and materials]. Bilbao: Desclée de Brouwer.

Buxarrais, M. R., Martínez, M., Puig, J. M., \& Trilla, J. (1995). La educación moral en primaria y en secundaria [Moral education in elementary and secundary education]. Barcelona: Edelvives.

Buxarrais, M. R., \& Zeledón, M. P. (2006). Las familias y la educación en valores democráticos. Retos y perspectivas actuales [Families and education in democratic values. Current challenges and perspectives]. Barcelona: Claret.

Carr, D. (2008). Character education as the cultivation of virtue. In L. Nucci \& D. Narvaez (Eds.), Handbook of moral and character education (pp. 99-116). New York, NY: Routledge.

Colby, A., \& Kohlberg, L. (1987). The measurement of moral judgment. Cambridge: Cambridge University Press.

Cortina, A. (1993). Ética aplicada y democracia radical [Applied ethics and radical democracy]. Madrid: Tecnos. 
Davis-Kean, P. (2005). The influence of parent education and family income on child achievement: The indirect role of parental expectations and the home environment. Journal of Family Psychology, 19(2), 294.

Doris, J. (2010). Lack of character. Personality and moral behaviour. New York, NY: Cambridge University Press.

Dunn, J. (2006). Moral development in early childhood and social interaction in the family. In M. Killen \& J. Smetana (Eds.), Handbook of moral development (pp. 331-350). Mahwah, NJ: Lawrence Erlbaum Associates.

Epstein, J. (2018). School, family, and community partnerships: Preparing educators and improving schools. New York, NY: Routledge.

Gibbs, J. (2003). Moral development and reality: Beyond the theories of Kohlberg and Hoffman. Thousand Oaks, CA: Sage Publications.

Graell, M. (2015). Los centros educativos y las entidades sociales deben establecer relaciones de colaboración. In J. M. Puig (Ed.), 11 ideas clave ¿Cómo realizar un Proyecto de aprendizaje servicio? [11 Key ideas. How to realize a service-learning project], (pp. 65-76). Barcelona: Graó.

Greenhaus, J., \& Powell, G. (2006). When work and family are allies: A theory of workfamily enrichment. Academy of Management Review, 31(1), 72-92.

Halstead, J. (1999). Moral education in family life: The effects of diversity. Journal of Moral Education, 28(3), 265-281.

Hartshorne, H., \& May, M. (1930). A summary of the work of the character education inquiry. Religious Education, 25(7), 6o9-611.

Henderson, A., \& Mapp, K. (2002). A new wave of evidence: The impact of school, family, and community connections on student achievement (Annual Synthesis, 2002). Austin, TX: Center of Family and Community Connections with Schools.

Hoyos, G., \& Martínez, M. (2004). ¿Qué significa educar en valores hoy? [What does it mean to educate in values nowadays?]. Barcelona: Octaedro.

Kant, I. (1785/2008). Fundamentación de la metafísica de las costumbres [The groundwork of the metaphysics of morals]. Madrid: Espasa-Calpe.

Kohlberg, L. (1981). The meaning and measurement of moral development. Worcester, MA: Clark University Press.

Kohlberg, L. (1984). Essays on moral development. The psychology of moral development. San Francisco, CA: Jossey-Bass.

Kozma, R. B. (2011). A framework for ICT policies to transform education. In R. Kozma (Ed.), Transforming education: The power of ICT policies (pp. 19-36). Paris: UNESCO. Kymlicka, W. (1989). Liberalism, community and culture. Oxford: Oxford University Press.

Lapsley, D., \& Clark, F. C. (2005). Character psychology and character education. Notre Dame, IN: University of Notre Dame Press. 
Laredo, P. (2007). Revisiting the third mission of universities: Toward a renewed categorization of university activities? Higher Education Policy, 20(4), 441-456.

MacIntyre, A. (2009). The very idea of a university: Aristotle, Newman and us. British Journal of Education, 57(4), 347-362.

Noddings, N. (2008). Caring and moral education. In L. P. Nucci \& D. Narvaez (Eds.), Handbook of moral and character education (pp. 161-174). New York, NY: Routledge.

Nucci, L., \& Narváez, D. (Eds.). (2008). Handbook of moral and character education. New York, NY: Routledge.

Osler, A., \& Starkey, H. (2006). Education for democratic citizenship: A review of research, policy and practice 1995-2005. Research Papers in Education, 21(4), 433-466.

Oxley, L., \& Morris, P. (2013). Global citizenship: A typology for distinguishing its multiple cownceptions. British Journal of Educational Studies, 6r(3), 301-325.

Pérez, A. (2007). Principales modelos de socialización familiar [Main models of family socialization]. Foro de educación, 5(9), 91-97.

Pigozzi, M. (2006). A UNESCO view of global citizenship education. Educational Review, 58(1), 1-4.

Prinz, J. (2009). The emotional construction of morals. New York, NY: Oxford University Press.

Puig, J. (2012). Compromís cívic i aprenentatge a la universitat. Experiències de l'aprenentatge servei [Civic commitment and learning in the university. Servicelearning experiences]. Barcelona: Graó.

Puig, J., Batlle, R., Bosch, C., \& Palos, J. (2006). Aprenentatge servei. Educar per a la ciutadania [Service-learning. Educating for citizenship]. Barcelona: Octaedro.

Puig, J., \& Martín, X. (1998). La educación moral en la escuela. Teoría y práctica [Moral education in schools: Theory and practice]. Barcelona: Edebé.

Rawls, J. (1971). A theory of Justice. Cambridge, MA: Harvard University Press.

Rest, J. (1986). Manual for the defining issues test. Minneapolis, MN: Center for the Study of Ethical Development.

Rüegg, W. (Ed.). (1996). A history of the University in Europe. Vol II. Universities in the Modern Europe. Cambridge: Cambridge University Press.

Sennet, R. (2000). La corrosión del carácter [The corrosion of character]. Barcelona: Anagrama.

Steiner, G. (2004). The idea of Europe. Tilburg: Uitgeverij Nexus.

Tirri, K., \& Nokelainen, P. (2011). Measuring multiple intelligences and moral sensitivities in education. Rotterdam, The Netherlands: Sense Publishers.

Turiel, E. (1984). El Desarrollo del Conocimiento Social. Moralidad y Convención [The development of social knowledge: Morality and convention]. Madrid: Debate.

UNESCO. (2006). UNESCO guidelines for intercultural education. Paris: Author. Retrieved from https://unesdoc.unesco.org/ark:/48223/pfoooo147878 
Veugelers, W. (Ed.). (2011). Education and humanism. Linking autonomy and humanity. Rotterdam, The Netherlands: Sense Publishers.

Veugelers, W., De Groot, I., \& Stolk, V. (2017). Research for cult committee - Teaching common values in Europe. Brussels: European Parliament, Policy Department for Structural and Cohesion Policy. Retrieved from http://bit.ly/2pm5Yh9

Walker, J. L., \& Taylor, J. H. (1991). Family interactions and the development of moral reasoning. Child Development, 62, 264-283.

Williams, A. L., \& Merten, M. J. (2011). iFamily: Internet and social media technology in the family context. Family and Consumer Sciences Research Journal, 4O(2), 150-170. 